\title{
Ways of Knowing in Times of Destabilization
}

Kneller Lecture 2020

\author{
Leigh Patel \\ University of Pittsburgh
}

On March $7^{\text {th }}, 2020$, I had the distinct honor of delivering the Kneller lecture at the Philosophy of Education Society's annual conference. I titled the talk "Ways of Knowing" as a hat tip and acknowledgement of my colleague, Mike Gunzenhauser, who has extended nothing but generosity since I was first recruited to join the University of Pittsburgh. Ways of Knowing is a course that Mike had taught several times, but he displayed the opposite of territoriality, and asked me if I might like to teach this course that he had developed and adapted over many years. Leading up to the conference, the conference president, Cris Mayo and I spoke several times, with Cris offering detailed context about the association and its history. Although I was an outsider to this particular professional organization, and, as I always am, an uninvited guest on Indigenous lands, the flow and format felt familiar: work out tech issues, stay after the talk to interact with people who often tell me what meanings they made of the talk and how it relates to their work. True to so many other talks I have provided, one person asked me if I wouldn't mind sending him the Power Point presentation that I had used to structure the talk, a request that I have heard before and one that echoes the erasure of women of color's intellectual work. So far, not much was unusual to the ongoings of academic convenings: generosity of spirit, as well as tendrils and re-enactments of the individualized and sometimes opportunistic ways of being in the academy.

I refresh these details to mark my experience of the Philosophy of Education conference as neither new nor surprising to me. There was generosity, thoughtfulness in every step leading up to the talk, as well as retread conversations in which academics, so deeply expert in their areas, often engage in dialogues with other academics by first articulating their research interests. It has long been a cultural practice, a shared way of doing, knowing, and acting 
for academics to listen to another academic and then start a sentence with a version of: "That's interesting. What I'm interested in is..." I say this to name explicitly the ways of knowing and the forms of relationality, or rather the lack thereof, in the highly individualized and competitive culture of academe that is in no way exclusive to philosophers of education.

Eleven days after delivering the Kneller talk, mine and other campuses across the nation and the planet closed their campuses, scrambling to mediate and contend with the impact of COVID-19. In a matter of days most faculty and administrators gradually found spaces in their homes where they would then pass hours staring at the green light of the computer cameras in online meetings. For students who had access to technology, including computer broadband internet, the adjustments to online courses were annoying and a poor match for the physical energy of bodies, objects, and tools in the shared same physical space.

Our ways of knowing have been altered, in some cases regrounded in foundational principles of learning as relational because we have missed being able to do so in shared physical spaces. In other cases, our ways of knowing have been made to reckon, again, with the long-standing patterns of societal inequity. Black and white students who participated in university programming returned to their homes to discover and remember that they, in fact, came from drastically different socioeconomic and political social location. ${ }^{1}$

Lastly, ways of knowing have been demanding attention about the global phenomenon of racism, with global uprisings against and responses to long-standing patterns of anti-Black violence delivered through law enforcement officials and vigilantes. Although the mortal consequences of systemic racism were predictable, the statistics and material loss, large-scale lack of wellness, and lack of access to healthcare has provided harrowing statistics of who has fallen ill, suffered from mental health burdens, and died from COVID-19: predominantly Black, migrant, and Indigenous peoples. In New Orleans, a city with a large Black population, and the site of many Black freedom struggles, including the removal of confederate monuments built in the 1960s to stave off 
the civil rights movement, more than 70\% of COVID deaths have been Black Americans. ${ }^{2}$ This city in particular highlights the fact that COVID hooked into existing disparities between access to health care, reliable public transportation, and food deserts.

\section{WHO IS SAFE AND WHO IS NOT?}

Ways of knowing safety and wellness are both somatic and driven by durable yet always permeable culture and policy. Culture is, at its most reduced definition, shared ways of being, doing, and acting. ${ }^{3}$ Policies here defined as de jure laws and policies that, along with cultural practices create starkly different material realities of literal life and death.

An obvious and glaring example of racialized proximity to population-level acceleration to illness and death has always been a fact in the United States. ${ }^{4}$ However with the pandemic and its increasingly glaring and cruel impacts on working class Black, brown, and Indigenous peoples, were reminders to mainstream, specifically white people who could physically distance and experience no interruption to their income or access to healthcare that the social structure daily manifested statistics in which racism, poverty, and health insecurity were headlines. Frontline workers, a term often reserved for people in direct combat with people named as enemies, included grocery cashiers, people who stocked shelves in stores, truck drivers, and delivery agents, to name a few. Unsurprisingly, as these workers could not financially opt out of work, such as driving a public transportation bus, were eulogized as essential but materially were treated as expendable.

At the same time, people who could work remotely and did not face material effects that put them at risk of illness and death, hopefully had to contend with the fact that their safety was intimately connected to lack of safety of others. For example, pre-ordering food from a grocery and driving up to have it brought to one's car is a stark example of the long-standing chasm between those of means and those whose safety is in constant question because they simply cannot choose not to show up to work. 


\section{WAYS OF KNOWING INTERCONNECTEDNESS}

Once virtually every public and private space was shuttered, people began to know, deeply that our lives and actions are deeply intertwined. Loneliness and isolation were foils to families being able to shelter in place and renew the depth of their bonds. At the same time, many people sheltered in place with a family or community member who had been abusing them for years.

However people decided to defy or were forced to cross shelter in place orders, their actions impacted them and everyone they came into contact with. For example, in mid-March 70 students enrolled at the University of Texas, Austin, chartered a plane to fly to Mexico for their Spring Break. To date, 40 of those 70 young people have tested positive for the virus and returned to Austin, in which $10 \%$ of the city is elderly, resulting in Austin joining other cities experiencing a second surge of the virus in the summer that peaked higher than the first peak in April.

For long-standing Indigenous ways of knowing, the fact that all living beings are intertwined is neither new nor revelatory. Kawagley's $A$ Yupiak way of Knowing concisely articulates that ways the Yupiak peoples' interconnectedness with land, air, waterways have been impacted by contact with European and euro-descended settlers' ways of being: snowmobiles, oil drilling, and the killing of animals for sport or mass profit rather than for more localized needs. ${ }^{5}$

Relatedly, people who had never considered the planet as a lifeform unto itself were being told through various media outlets that large outbreaks of the virus in meat processing plants might, to put it mildly, require a reconsideration of how we know and are in relation with animals, the air, water, and the planet. ${ }^{6}$ As a person who attended secondary and university education in the Midwest, I witnessed both the demise of family farms and the rise of large meat processing plants. I recall farmers receiving subsidy checks to NOT grow more of their crops, as international trade proved to be cheaper with the government acting as intermediary. With these moves came economic devastation to family-owned farms, myriad small towns becoming ghosts of thriving agricultural practices, 
and a lost ethos of raising healthy animals and then making use of as many of their offerings after being slaughtered. Those are now a historical practice having given sway to large-scale companies whose interests are to use chemical hormones to bolster the animals' growth so that they would that much more quickly be slaughtered, processed, and placed in Styrofoam and plastic wrapped containers on grocery shelves. However, it's important to note that even during the era of family-owned farms, this property ownership was reserved almost exclusively for white men. Their epistemologies were in closer relation to the land, more attentive to rainfall and early frosts, but most still operated from the stance that land is property, and farm animals were valued for their potential profit after slaughter. The Morrill Acts that created land grant institutions from and on top of Indigenous lands, is another iteration of these ways knowing through property and expectation of property rights.

COVID-19 and its outbreak in many areas, including meat processing plants raised questions that have long lingered about the safety of workers in these factories, most of whom are migrants, many without legal documentation to be in the United States. The seated president of the United States, a life-long racist, contended that the virus would be quickly solved and insisted on the re-opening of meat-packing plants before he urged governors to re-open their states' businesses. At the time of this writing, the pandemic is in a second surge, much higher than the first surge in April of 2020.

From the perspective of many Indigenous nations and tribes, land is not property: a capital to be owned. Nor is it a resource to be tilled. It is a lifeforce. It is ancestor. It is future child. All of ways of knowing, or more accurately put, being in relation to the planet, are grounded in the inextricable relationship amongst all living beings, which demands being in right relationship to land, air, and waterways. ${ }^{7}$ This way of knowing holds respect for elders and ancestors, but unlike the academy, it does not seek to reproduce static forms of elder's characteristics; neither does it insist upon highly individualized and competitive cultures. For many Native peoples, individualism and competition is anathema to their ways of being for time immemorial. 


\section{WAYS OF KNOWING INTERVENTIONS IN COLONIALISM AS A CONSTANT DYNAMIC}

At the same time that the COVID-19 pandemic halted business and social activities across the globe, some practices persisted and intensified: the long-standing practice of racializing diseases to have an enemy, concentrated harm to Indigenous peoples due to lack of social services and long-standing efforts to contain and erase them, and finally, the ongoing murder of Black people by law enforcement or white vigilantes. In fact, anti-Black racism has been a global phenomenon for centuries. In the United States, George Floyd's breath was literally squeezed out him by an officer who placed his knee on Floyd's neck, with his hands in his pockets for almost nine minutes. In February Ahmaud Arbery, a Black man jogging on a narrow street in Georgia, was cornered by two vehicles driven by white men and shot to death after struggling for his life. Breonna Taylor was in her home when four police officers with a no-knock order, meaning that they needed neither to identify themselves nor request entry, shot her partner in the leg, and shot her seven times. She died immediately. These and many other killings of Black and brown people led to an uprising. About a week after Floyd's execution, protests were occurring in all 50 states, and then spread across the globe. As it turns out our ways of knowing that Black Lives Matter can, like all ways of knowing, change and expand over time.

Along with the protests about anti-Black racism and the cries for cessation of racism towards Chinese appearing people, came specific demands and adroit analyses. The student activists at the University of Minnesota have articulated their demand clearly, holding a rally on campus with the message: Get the police off our campus. The then president of the American Studies Association issued a statement calling the global uprising a rebellion and making the important distinction that a rebellion is not a revolution but can be a revolution.

\section{WAYS OF KNOWING REGIONAL LEADERFULL AND SUSTAINING FIGURATIONS OF CONNECTIONS}

As educators, the ways of knowing what constitutes being in right rela- 
tion with all living beings and knowing deeply the intertwined and shapeshifting patterns of white, heteropatriarchal capitalism is part of our moral duty. It is striking within the population of full professors in the United States, roughly 2.2 percent are Black women. This is not accidental nor a reflection of a lack of grit, growth mindsets. It reflects how the United States rose to global prominence through stolen labor on stolen land. In fact, enslaved Black women were valued highly as property precisely because they were able to produce more chattel slaves, babies. Insurance companies were started to insure enslaved black lives for their white slave owners' property ownership.

\section{LEARNING FROM EMERGENCE DURING PANDEMICS}

What are ways of knowing that should be foundational to a philosophical organization dedicated to education? While different in form and, I would argue, purpose, there are many examples to learn from. In Emergent Strategy, adrienne marie brown proposes that there are emergent communities, practices, and knowledges coming into fruition constantly. The pointed question is if we engage in these or use the disciplines of the academy to tamp down these emergent and revolutionary knowledges and relations.

I write this essay during a time of global health crisis and anti-racist rebellions. This is a leaderfull moment, with people being restricted from gathering together physically, they have found ways to gather, ways to teach, ways to imagine a new world into existence. Roy reminds us that pandemics have always been portals, opportunities to imagine new worlds into existence. ${ }^{8}$ She poses that to do so would mean stepping lightly through the portal, with luggage and leaving behind individualism, hatred for racial and ethnic scapegoats. Further, the Movement Generation, which offered a strong series of programming during the summer of 2020 states:

It took $500+$ years of increasing domination of the land to bring on this pandemic. The decisions that caused it were made far from the places of impact. In fact, governance and decision-making are at the root of the crises of our 


\section{times-from speculative housing markets to global indus- trial food systems and toxic fossil fuel industries. How can we move towards local, loving, linked, participatory economies for life? What unjust rules do we need to break? What new practices do we need to codify to move from political borders to ecological boundaries??}

This is in fact, a radical analysis and a literal example of what it means to imagine a new world into existence. Educators like Septima Clarke and Anna Julia Cooper, sociologists such W.E.B. DuBois and historians like Barbara Ransby and Robin DG Kelley are some of the public intellectuals whose actions were both word and deed, all undergirded by philosophical inquiry and reflection. It has always been the right time to unfurl our grip on epistemologies and traditions that forward property and individualism. I hope that we learn from these traditions to reshape what it means to be a philosopher of education.

1 Nicholas Casey, "Colleges made them feel equal: The virus exposed how unequal their lives are," New York Times, May 5,

2020, https://www.nytimes.com/2020/04/04/us/politics/coronavirus-zoom-college-classes.html.

2 Gordon Russell \& Sam Karlin, "Coronavirus disparity in Louisiana: About $70 \%$ of the victims are Black, but why?" The Times-Picayune, April 6, 2020, https://www.nola.com/news/coronavirus/article_d804d4107852-11ea-ac6d-470ebb61c694.html.

3 Stuart Hall, Cultural studies 1983: A theoretical history (Duke University Press, 2016).

4 Ruth W. Gilmore, Golden gulag: Prisons, surplus, crisis, and opposition in globalizing California (University of California Press, 2007).

5 Angayuqaq O. Kawagley, A Yupiaq worldview: A pathway to ecology and spirit (Long Grove, IL: Waveland Press, 2006). 
6 Eve. Tuck \& Marcia McKenzie, Place in research: Theory, methodology, and methods (London: Routledge, 2014).

7 Manulani A. Meyer, "Indigenous and authentic: Hawaiian epistemology and the triangulation of meaning," Handbook of critical and Indigenous methodologies (2008), 217-232.

8 Arundhait Roy, “The pandemic is a portal," Financial Times, April, 3, 2020, https://www.ft.com/content/10d8f5e8-74eb-11ea-95fe-fcd274e220ca.

9 adrienne $\mathrm{m}$. brown, Emergent strategy: Shaping Change, Changing Worlds (Chico, CA: AK Press, 2017); Movement Generation (2020). Accessed June 1, 2020: https://movementgeneration.org/. 